DOI: https://doi.org/10.32782/2410-0927-2020-12-23

УДК 373.091.214.18-027.556:811.111]:004](477)(045)

Алла Павлюк, Свімлана Шелуденко, Ольга Шелуденко

\title{
ЗАЛУЧЕННЯ ІНФОРМАЦІЙНО-КОМУНІКАЦІЙНИХ ТЕХНОЛОГІЙ ПРИ ОРГАНІЗАЦІЇ ФАКУЛЬТАТИВНИХ ЗАНЯТЬ АНГЛІЙСЬКОЇ МОВИ НА ЗАСАДАХ ІНТЕГРАТИВНОГО ПІДХОДУ В 5-6 КЛАСАХ СЕРЕДНЬОЇ ШКОЛИ
}

Статтю присвячено експериментальним курсам i факультативним заняттям як засобу розширення мовленнєвого простору в середній школі. Встановлено передумови залучення інформаційно-комунікаційних технологій. Акцентовано на актуальності питання інформаційно-комунікаційних технологій в освіті 3 огляду на 10 компетентностей Нової української школи. Окреслено важливість відеометоду як оптимальної форми організації факультативних занять англійської мови на засадах інтегративного підходу. Простежено кореляцію сучасних засобів унаочнення та сформованої лінгвокультурної компетенції.

Зіставлено поняття Information Technology та Information and Communication Technology 3 подальшим виявленням відмінностей у їх змістовому наповненні. Актуалізовано поняття інформаційно-комунікаційних технологій як інтенсифікатора навчального процесу, що мотивує здобувачів освіти, забезпечуючи формування лінгвокультурної компетенції.

Окреслено змістове наповнення модуля «Земля: подорож у часі» експериментального курсу «Крізь епохи та континенти», що сприяє успішному засвоєнню мовного матеріалу в ігровій формі. Виокремлено вісім тематичних блоків, а саме: «Льодовиковий період», «Великий шовковий шлях», «Дарвін і теорія еволюції», «Географічні відкриття минулого та перша навколосвітня подорож», «Піраміди Єгипту», «7 чудес Стародавнього світу», «Як відкрили світ рослин», «Вікінги», що становлять змістовий модуль, присвячений короткому екскурсу в історію планети та великих географічних і наукових відкриттів.

Доведено компліментарність «кейс»-методу, який у формі ситуативних вправ сприяє формуванню ерудованої, соціально активної особистості здобувачів освіти, з розвиненим мисленням та здатністю самостійно, активно і творчо розв'язувати поставлені практичні завдання. Визначено позитивний вплив «кейс»-методу при навчанні здобувачів освіти поколінь Z та Альфа з кліповим мисленням.

Проілюстровано зразки завдань та ситуативних вправ окремих тематичних блоків змістового модуля «Земля: подорож у часі». Підкреслено важливість поєднання відеометоду з книжковими фрагментами задля реалізації освітніх цілей. Продемонстровано комплекс вправ на прикладі тематичного блоку «Вікінги».

Ключові слова: відеофрагмент, експериментальний курс, інтеграція, інформаційно-комунікаційні технології, освітній простір.

Вступ. Запровадження реформи в галузі освіти у 2017-2018 роках ініціювало великі зміни у навчальному процесі. 3 огляду на 10 компетентностей, що є ключовими в новій українській школі, спілкування іноземними мовами у широкому діапазоні соціальних і культурних контекстів є не просто базовою компетенцією, а й запорукою успішної реалізації виховних, загальноосвітніх i розвивальних цілей навчання [9]. Успішна реалізація компетентності спілкування безпосередньо залежить від вибору форм, стратегій і технологій, що сприяють організації освітнього процесу.

Пошук ефективних технологій навчання іноземної мови незмінно перебуває у фокусі уваги вітчизняних науковців, особливо в контексті Нової української школи. Дослідниці В.Ф. Паламарчук та О. В. Барановська розробляють питання, пов'язані 3 технологізацією освітнього процесу Нової української школи та комплексному впровадженню інноваційних підходів [10]. Вагомий внесок у розвиток інтерактивних технологій навчання іноземної мови зроблено професором В. Н. Редьком. Учений не лише формулює теоретичні засади та наводить приклади використання інтерактивних технологій у шкільній практиці, а й акцентує на можливості їх залучення до стимулювання іншомовної мовленнєвої діяльності учнів та утвердження партнерських стосунків [12]. Ольга Пінчук та Олександра Соколюк наголошують на проблемі своєчасності поширення освітніх інновацій для організації сучасного навчального середовища. Авторки розвідки про пізнавальну діяльність учнів в умовах цифрового перетворення навчального середовища привертають увагу до проблем організації освітньої та пізнавальної діяльності учнів та формування їхньої компетентності в контексті нових технологій [11].

(С) Павлюк А., Шелудченко С., Шелудченко О., 2020 
3 огляду на тенденції сучасного світу та прогрес у галузі цифрових каналів поширення інформації проблема імплементації сучасних засобів унаочнення, зокрема залучення освітніх відео до навчального процесу для формування лінгвокультурної компетенції, $є$ однією 3 нагальних, адже, як твердять Р. С. Гуревич, М. Ю. Кадемія, М. М. Козяр, «Технологічні засоби нового покоління дозволяють оперативно створювати контент, який $є$ надбанням усього суспільства, будувати мережі соціальної взаємодії, системи децентралізованого обміну знаннями та інформацією, одержуючи доступ до світових інформаційних ресурсів» [5].

Попри високі досягнення науковців у дослідженні й формуванні методів навчання лінгвокультурної компетенції на практиці постає необхідність оптимізації навчання та залучення новітніх технологій до освітнього процесу в базовій середній школі. Отже, маємо на меті аналіз результатів апробації завдань, що включені до другого змістового модуля експериментального курсу «Крізь епохи та континенти» (практичну апробацію було здійснено на базі КЗ «Луцька загальноосвітня школа № 19» в 2018-2019 та 2019-2020н.р.). Задля успішної реалізації мети необхідно розв'язати окремі завдання, а саме: 1) установити закономірності навчання школярів 3 опорою на відеофрагменти; 2) підібрати зорово-слухові матеріали навчання для формування лінгвокультурної компетенції (з огляду на вікові та психологічні особливості школярів); 3) розробити зразки вправ для навчання учнів поколінь $Z$ та Альфа; 4) експериментально апробувати систему вправ при роботі з освітніми анімаційними відео відповідно до теми заняття.

Методи та методики дослідження. Інформаційно-комунікаційні технології в освіті - це потужний ресурс, який попри низку грунтовних студій становить інтерес для дослідників, що працюють у цій царині. Так, загальним питанням інформаційно-комунікаційних технологій в освіті присвячували свої роботи Т. І. Коваль, І. В. Ставицька, Г. Г. Швачич та інші. Професор В. Ф. Заболотний акцентував дослідження на дидактичних засадах використання мультимедіа [20]. Дослідник В. Ю. Биков висвітлює питання, присвячені моделям організаційних систем відкритої освіти [2], а професор Г. О. Козлакова вивчала теоретичні й методичні основи застосування інформаційних технологій у вищій технічній освіті й інформаційно-програмне забезпечення дистанційної освіти [6].

Результати та дискусії. Критичний аналіз дефініцій, а саме Information Technology (the technology involving the development, maintenance, and use of computer systems, software, and networks for the processing and distribution of data) [7] та Information and Communication Technology (technologies that provide access to information through telecommunications. It is similar to Information Technology (IT), but focuses primarily on communication technologies. This includes the Internet, wireless networks, cell phones, and other communication mediums) [17] призводить до логічного висновку, що інформаційно-комунікаційні технології є незамінними при викладанні іноземної мови, адже вони інтенсифікують навчальний процес, сприяють підвищенню мотивації до вивчення мови, уможливлюють швидке формування великої кількості елементів спонтанного мовлення і мовленнєвих кліше, забезпечують формування лінгвокультурної компетенції учнів. Визнаємо, що інформаційно-комунікаційні технології $\epsilon$ компліментарними і для традиційних занять іноземної мови, і для занять на засадах інтегративного підходу. Під інтегративним підходом (за дослідниками, що долучилися до розробки проєкту Нової української школи) розуміємо процес взаємодії, об'єднання, взаємовпливу, взаємопроникнення, взаємозближення, відновлення єдності ... двох або більше систем, результатом якого є утворення нової цілісної системи, яка набуває нових властивостей та взаємозв'язків між оновленими елементами системи [8].

До програмного забезпечення, яке, на думку Ю. М. Буровицької, разом із апаратними засобами складають інформаційно-комунікаційні технології сьогодення, відносять Інтернет i його інструменти (електронна пошта, браузери, веб-сайти, пошукові системи, форуми, аудіо- та відеочати), засоби IP-телефонії, платформи для мережевих курсів, блоги, мікроблоги, сервіси для зберігання фото, відео, презентацій, контактні сервіси, smart-технології, хмарні технології, геосервіси. Дослідниця підкреслює: «Зрозуміло, що успіх впровадження інформаційнокомунікаційних технологій у навчальний процес залежить не від того, якими технічними засобами користується викладач, а від того, як саме він його використовує» [1]. 
У сучасній школі одним із поширених різновидів $є$ відеометод. Під відеометодом розуміють наочний багатофункціональний метод навчання, який полягає у використанні відеоматеріалів і активізує наочно-чуттєве сприймання, забезпечує більш легке і міцне засвоєння знань у їхній образно-понятійній цілісності та емоційній забарвленості [18]. При комунікативному викладанні саме відеометод забезпечує найточніше відображення мови в користуванні, ii актуалізацію конкретними мовцями, зв'язок із реальною ситуацією, а комунікативна мета підсилюється цілим рядом візуальних закодованих немовних характеристик. Використання відеозаписів на заняттях сприяє індивідуалізації навчання та розвитку мотивованості мовленнєвої діяльності учнів.

Саме на використанні відеометоду акцентовано в другій частині методичних рекомендацій «Земля: подорож у часі» експериментального курсу «Крізь епохи та континенти» [15]. У методичних рекомендаціях, що є логічним продовженням першої частини «Подорож континентами» [14], презентовано настанови, які окреслюють специфіку залучення автентичних освітніх он-лайн ресурсів і відеофрагментів до занять у середній школі, й запропоновано тематичне наповнення змістового модуля «Земля: подорож у часі». Зміст занять сплановано за темами, що грунтуються на освітніх відеофрагментах з каналу «World Ahoy» [19], a caмe «The Ice Age», "The Silk Route», «Darwin \& the Theory of Evolution», "Geographical Discoveries \& the First Journey Around the World», "The Pyramids of Egypt», «7 Wonders of the Ancient World», "The Vikings» та «The World of Plants».

Зважуючись на розробку експериментального курсу, автори мали на меті організацію пізнавального процесу, який приноситиме радість дитині, збільшить час на творчість при широкому використанні в освітньому процесі дослідницької та проектної діяльності, мотивуючи учнів на здобуття знань та застосування їх у різних видах освітньої діяльності. Саме для цього частина завдань подана у вигляді «кейсів» або ситуативних вправ, що вперше були запроваджені ще в 1924 році в Гарвардській школі бізнесу. Кейс-метод є бенефіціарним, особливо коли

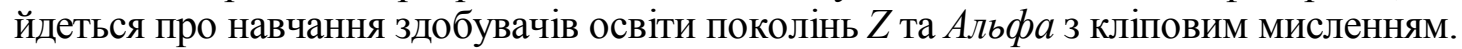

Як твердить літературознавець Раїса Савченко, кліповість мислення увійшла в наш буденний обіг за сприяння ЗМІ й вимагає облігаторного контексту, яким виступає об'єктивна дійсність. Небезпека тут полягає в тому, щоби окремі кліпи не склалися в хибну картину, адже «Головна загроза звички до кліпового мислення полягає в тому, що при цьому слабко розвиваються навички аналізу. Але ж ніхто не заважає вчителю стати саме тією ланкою, яка об'єднає інформаційні уривки єдиним контекстом та в рамках грамотно побудованого обговорення дозволить учням відчути інформаційну цілісність». Однак, суха логіка для поколінь $\mathrm{Z}$ та Альфа не є головним. Дослідниця наголошує, що «з часом діти вчаться створювати власні «кліпи», якщо отримують від вчителя відповідні завдання (придумати свою історію в картинках, власний сайт, журнал і т. ін.). I логічна послідовність цих кліпів випливає 3 власного досвіду дитини, а не з сухого зразка, наданого вчителем» [13].

3 метою унаочнення пропонуємо окремі вправи та ситуативні завдання, подані в методичних рекомендаціях на окремих кейсах, що яскраво ілюструють принципи підходу. Так, у темі «Льодовиковий період» пропонуємо уявити, як би існували визначні пам'ятки за екстремальних температурних умов льодовикового періоду, оскільки, як свідчить експериментальна апробація, діти краще запам'ятовують тематичну лексику «to be sneezing and coughing», якщо йдеться, наприклад, про Ейфелеву вежу, яка застудилася й демонструє подібні симптоми:
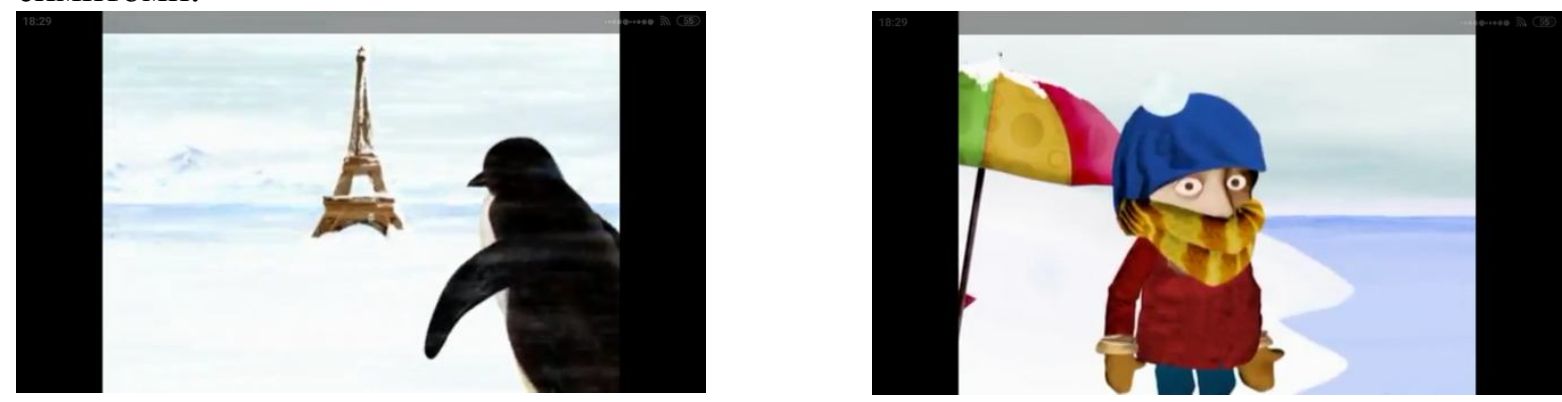
Imagine that the cities mentioned above experience the Ice Age. Follow the example in the video and comment on their state.

A video example: If there were no sunny and warm days, you would go to the beach wearing a scarf and two hats.

Make up sentences like this one: If there were no sunny and warm days in Venice, water in the Grand Canal would turn into ice.

Use the verbs: to survive, to freeze, to be damaged, to ruin, etc.

Тема «Шовковий шлях» оригінально презентує лексику «Caravanserais are fortified hostels», а згодом заохочує подорожувати Шовковим шляхом й порівняти оригінальний Шовковий шлях та осучаснений варіант.

USE: bandits, a caravan, caravanserais, silk, a silk worm, the Silk Route

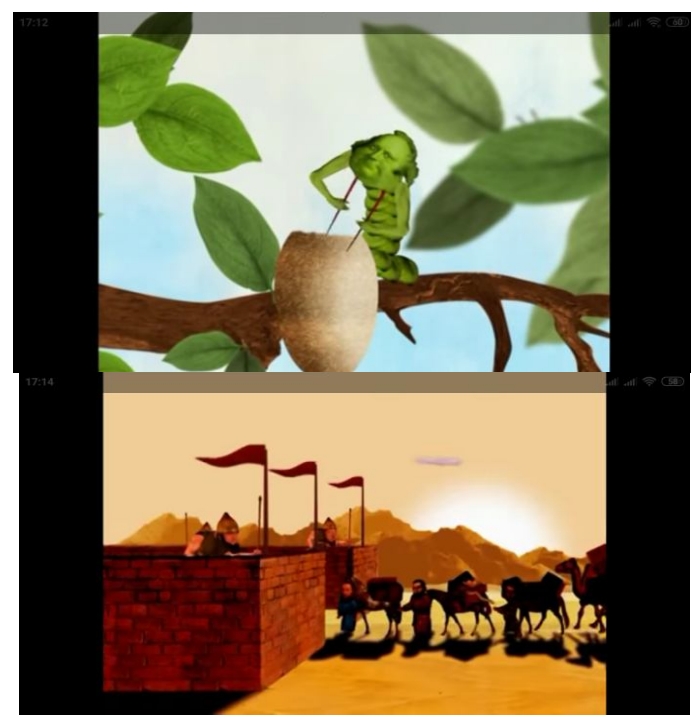

... is a creature that produces a precious type of threat.

Тема «Дарвін і теорія еволюції», яка не видається багатообіцяючою, у формі неструктурованого кейсу (unstructured cases, де подано велику кількість даних і $є$ низка можливостей для побудови власної відповіді), дає змогу простежити всі етапи становлення будьякої істоти за родинним деревом еволюції:

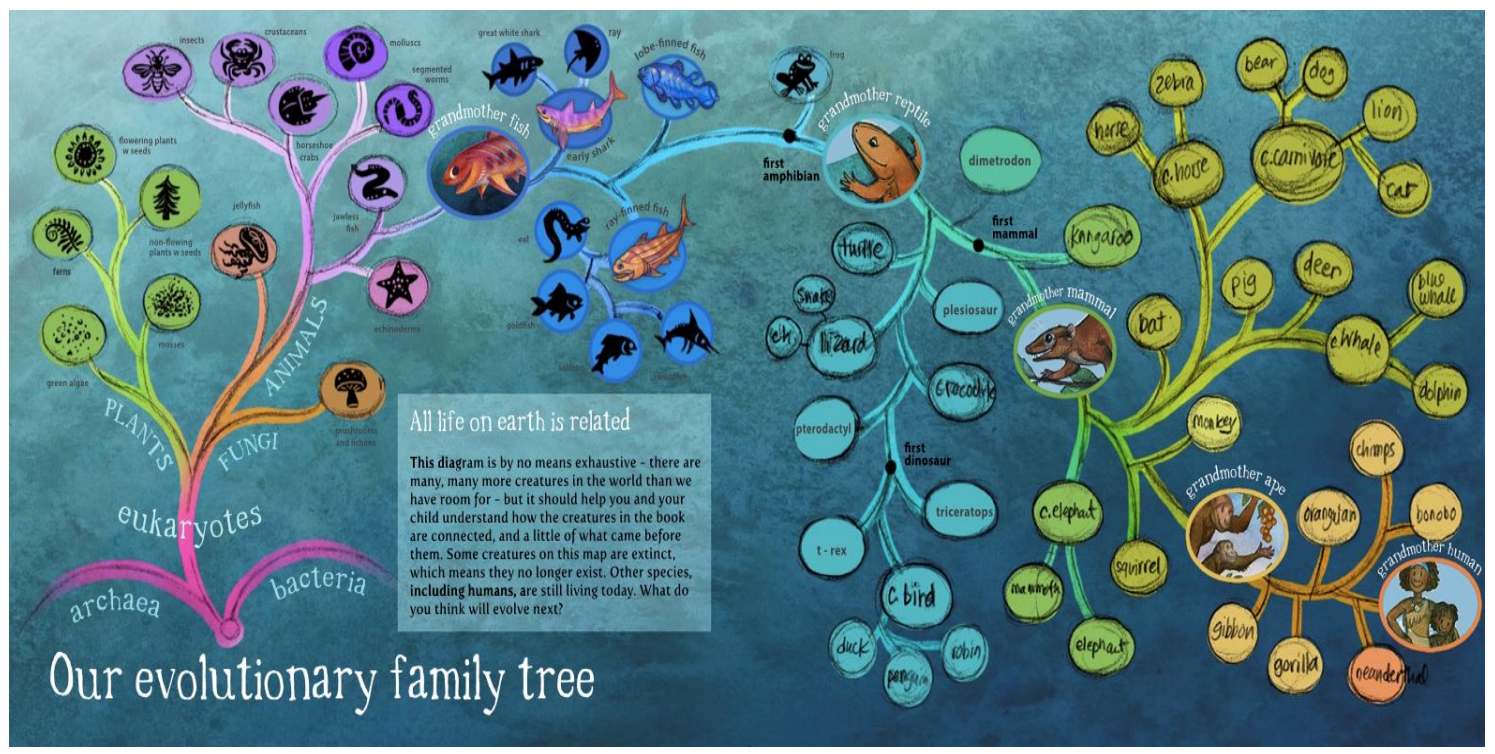

Comment on the ancestors / descendants of different animal species. Start like this: Gorilla is the descendant of grandmother ape. The ancestor of grandmother ape is... 
Тема «Піраміди Єгипту» допоможе школярам визначити, що вони знають про археологію, чи не злякаються стати археологом на літо та задіяти соціальні навички кооперативного навчання для пошуку скарбу, для чого використано новаторські «кейси» (ground breaking cases), які, зважаючи на індивідуальні риси здобувачів освіти, можуть варіюватись за обсягом, отож допомагають визначити рівень креативності та здатності до нестандартного мислення.

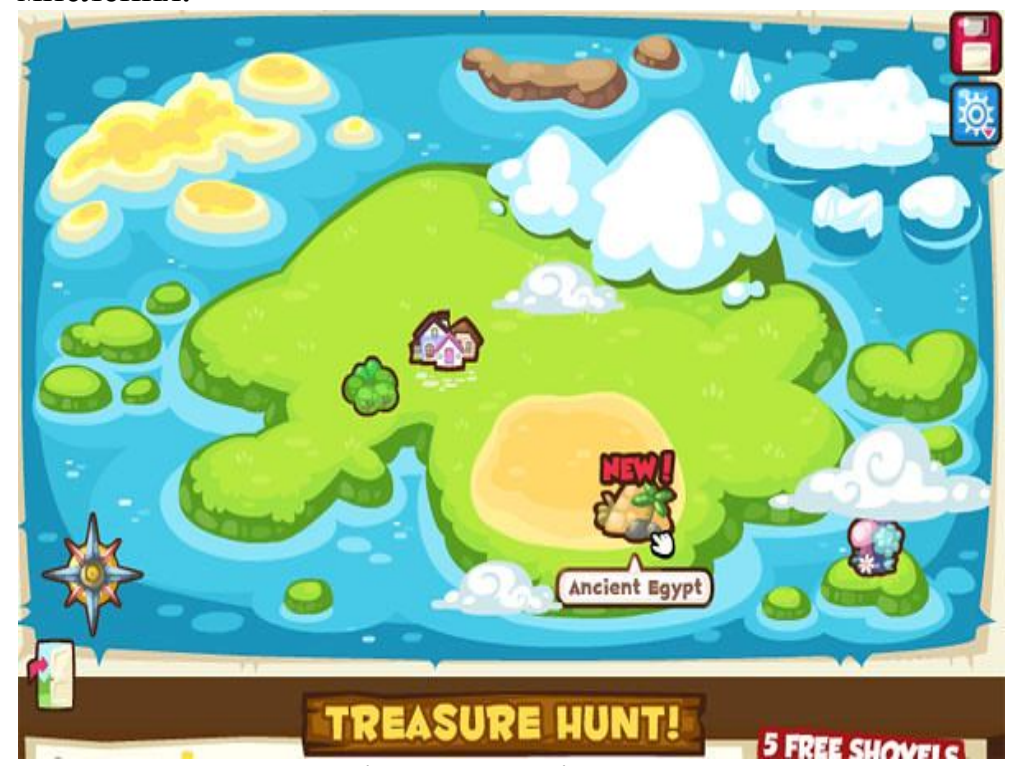

\section{Use the Map and Start your own search operation. Give clues:}

Have a look around. You are on the southern shore of the island

Тема «Як відкрили світ рослин» на яскравих прикладах у вигляді структурованих «кейсів» (highly structured cases) проілюструє, як людство експлуатує природу, допоможе зрозуміти імовірні наслідки та допоможе сформувати власні правила екотолерантності:

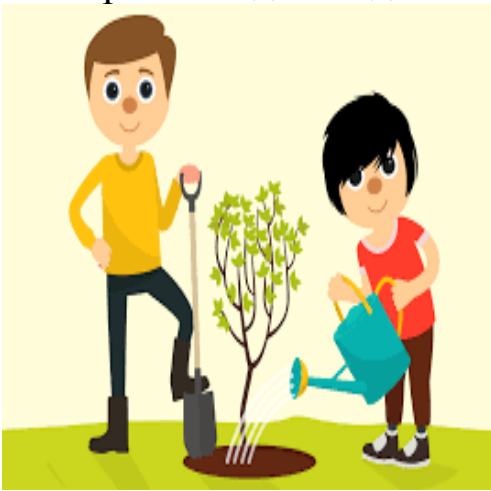

to plant trees

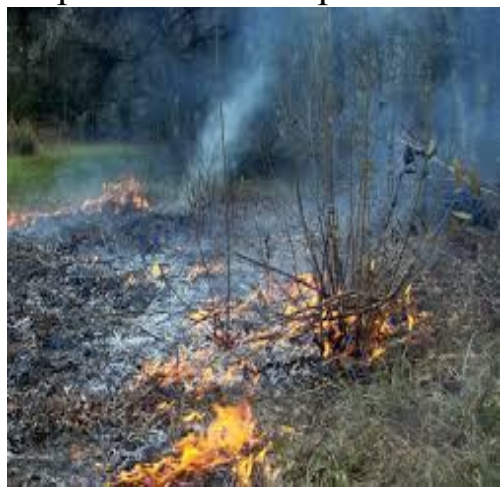

not to burn dry grass

\section{Plant trees to make your locality green and} friendly.

Методичні рекомендації - це повноцінна й вичерпна програма експериментального курсу, який завдяки активному залученню відеометоду допомагає краще запам'ятати мовні структури, розширити лексику і розвивати мовленнєві навички та навички аудіювання [4]. Деякі тематичні завдання присутні в кожній темі, водночас $є$ вправи, що подані як ситуативні завдання, які сприяють кращому запам'ятовуванню інформації, адже зумовлюють формування унікальної, відмінної від інших референції, що ілюструємо блоком завдань із теми «The Vikings».

На підготовчому етапі до першого перегляду відео пропонуємо ознайомитись із лексичними одиницями, поданими не лише транскрипційно, а й у супроводі зорової зображальної опори, проте без перекладу. 


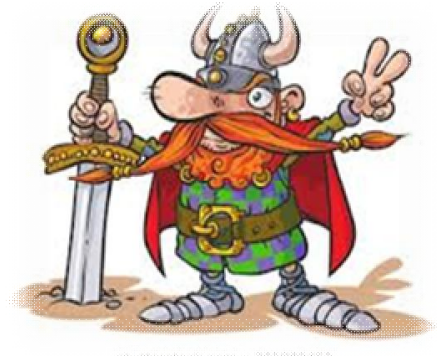

a warrior [ə 'wbriə]

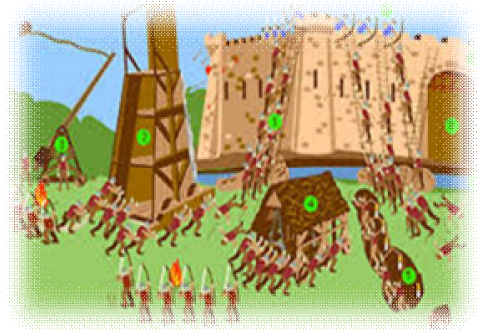

siege [si:d3]

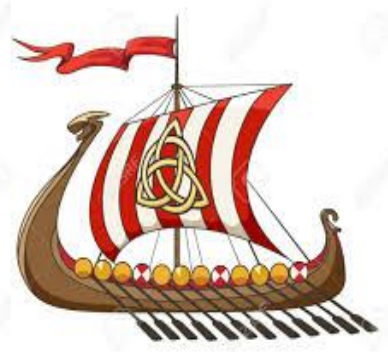

a drekkar / a drakkar

[ə 'dra:ka:(r)]

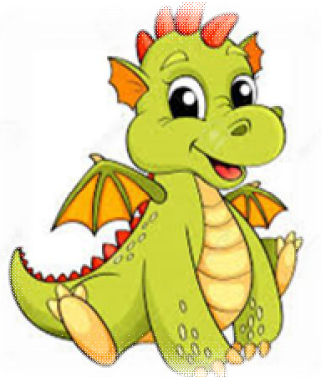

a dragon [ə 'drægən]

Під час першого перегляду відео пропонуємо визначити правильність / хибність уявлень про епоху вікінгів та ії представників, тобто здійснюється перегляд відеофрагменту 3 настановою на розуміння загального змісту, перевірка розуміння контенту.

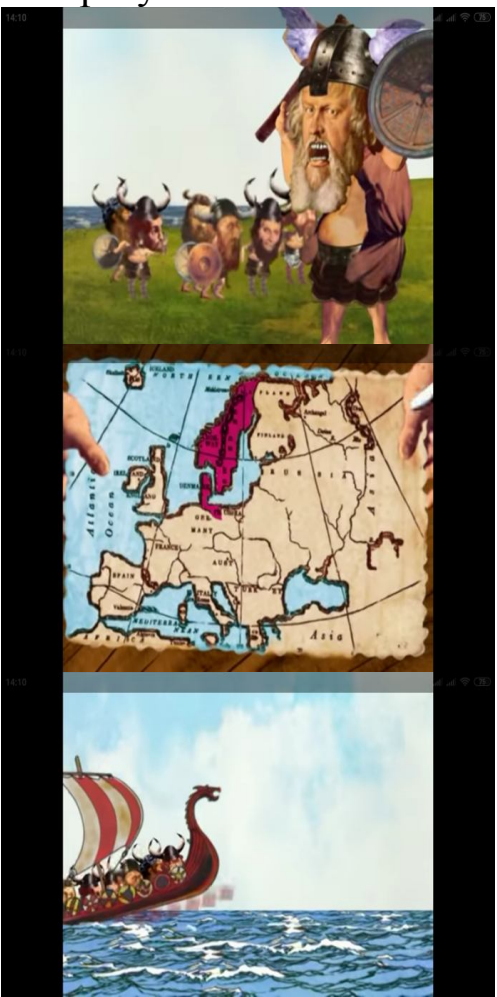

1) The Vikings were great warrior people.

2)

$$
\begin{aligned}
& \text { The Vikings came from the northern } \\
& \text { part of Europe. }
\end{aligned}
$$

\section{4) The Vikings used the drakkars to} travel and explore new lands.

Усвідомлюємо, що навчання поколінь $Z$ та Альфа корелює 3 проблемою навчання читання, тому вважаємо, що заняття з використанням інформаційно-комунікаційних технологій не слід будувати, базуючись лише на цифрових технологіях й інформаційних потоках. Натомість додаємо фрагменти для читання, а відповідне ситуативне завдання формулюємо в такий спосіб, щоб для його розв'язання слід було використати дані і з відеофрагменту і з уривка книги. Тому такі книжкові фрагменти слід відбирати ретельно, щоб інформація корелювала й доповнювала відеоряд. Покоління Z не можна змусити, натомість можна створити «кейс», який зможе зацікавити, обрати найяскравіше, найзахопливіше й бажано сучасне. У тематичному блоці «Тhе 
Vikings» послуговуємось дитячою книгою «A Viking Adventure» 3 cepiï «The Histronauts» [3]. Після ще одного перегляду відео (кількість переглядів відео відповідає кількості «кейсів», що $є$ запорукою активізації кліпового мислення) пропонуємо виконати таке завдання:

\section{Use the information from the book and fill in the gaps to describe the Vikings' currency:}

1) At first, the Vikings had no

2) The Vikigs used

3) Silver is a kind of

4) Ingots are objects to sell and buy

5) The Vikings metal.

6) The coins had a

7) The coins when they met new value. of coins always stayed the same.

VOCABULARY: coins, cultures, goods, pieces, precious, received, set, valuable, weight

I пропоновані завдання, i відео чітко відповідають критерію лінгвокультурної орієнтованості відеоматеріалів. Для відбору таких матеріалів використовуємо принципи визначення наявності соціокультурної інформації, які були виділені Л. П. Смєляковою, а саме: наявність соціокультурної інформації у змісті (ії діапазон та різноманітність); спосіб презентації соціокультурної інформації в тексті (рівномірний або нерівномірний); смислове навантаження соціокультурної інформації [16].

Відповідно до критерію автентичності вважаємо за потрібне відбирати автентичні відеоматеріали, створені саме з урахуванням вікових особливостей, оскільки маємо справу 3 школярами, котрі володіють ще невеликим багажем лінгвокультурних знань, а лінгвокультурні навички та вміння в них формуються поступово.

Match the words and the definitions to comment on the Vikings' sailing and Routine habits:

1) finding the way at sea

2) the star rising in the east

3) the point where the Sun sets

4) the way the Vikings are travelling to

5) 24 hours

6) places of destination

7) the star that helps to find the north

8) the tools that are used to find the right way

9) a magnetised piece of rock

10) a piece of crystal

11) indigo a) the west

b) a lodestone

c) the daytime

d) the direction

e) the Sun

f) navigational instruments

g) a blue dye

h) the navigation

i) Polaris

j) a sunstone

k) a map

На наступному етапі пропонуємо здобувачам освіти розробити власний маршрут для пошуку скарбів вікінгів із використанням карти та облігаторним уживанням набору дієслів.

Use the verbs: to go on, to pass by, to go along, to turn, to take the turning, to go across, to go through, to approach, to get to the destination, to walk, etc.

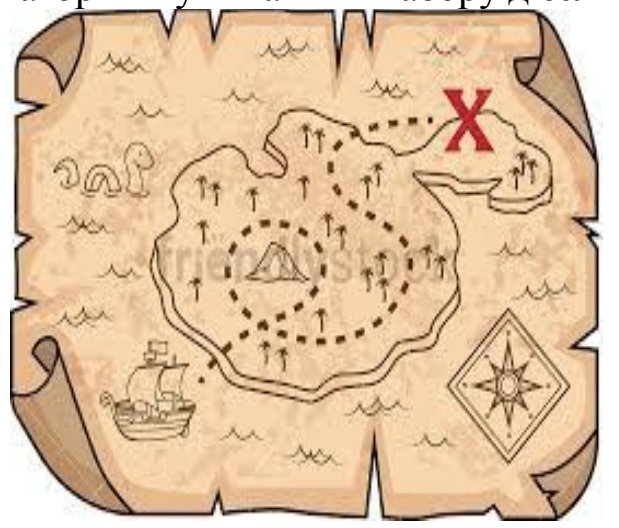


Ураховуючи, що візуалізація навчального матеріалу, створення навчального середовища 3 наочним представленням інформації, використанням кольору і звуку, впливаючи на емоційні та понятійні сфери, сприяє глибшому засвоєнню мовного матеріалу, формулюємо завдання, що свідчитиме про успішність процесу формування лінгвокультурної компетенції:

\section{Imagine you are a Viking. Use the map to comment on your contests Start like this: I'm a Viking warrior. I started from Sweden, went across Norway, and bought my drakkar there. First, I left for...}

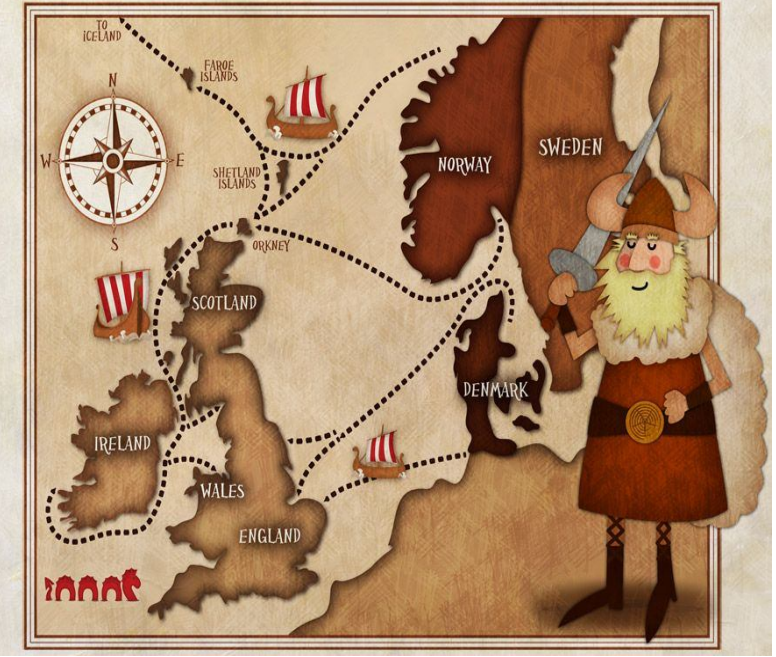

Отож, чільним вектором пропонованих ситуативних завдань $є$ комунікативна спрямованість із залученням мовленнєвих умінь на рівні, достатньому для здійснення іншомовного спілкування в усіх видах комунікаційної діяльності.

Висновки. Підсумовуючи результати апробації, дійшли висновку, що інформаційнокомунікаційні технології не лише допомагають реалізувати особистісний підхід до навчання, а й максимально наближають процес навчання до реальних умов життя. У сучасному світі відео використовують не лише в розважальному, а й у навчальному, виховному, соціальному аспектах. Учитель відповідає за створення якісного освітнього середовища, а розробка ситуативних завдань, або «кейсів», покликана розширити межі мовленнєвого простору. Відтак якісний освітній відеоконтент на уроках англійської мови забезпечує інтерес учнів до кожного тематичного блоку, провокує стійку увагу та спонукає до творчості попри те, до якого саме покоління (креативно орієнтованого чи ні) належать здобувачі освіти. Візуалізація сприяє запам'ятовуванню та реалізації компетентностей на практиці.

Перспективи подальших наукових студій вбачаємо в напрацюванні теоретичних засад для використання «кейс-завдань» з опорою на відеофрагменти та комп’ютерні ігри при навчанні англійської мови здобувачів освіти 7-8 класів з різними типами сприйняття інформації.

\section{References}

1. Burovytska, Yuliia. 2016. "Informatsiino-komunikatsiini tekhnolohii u vuschykh navchalnykh zakladakh: alhorytm vprovadzhennia". Pedahohichni nauky 133: 23-26.

2. Bykov, Valerii. 2009. Modeli orhanizatsiinykh system vidkrytoi osvity. Kyiv: Atika.

3. Durkin, Frances. 2019. A Viking Adventure (The Histronauts). North Star Editions; Reprint edition.

4. Frehan, Nataliia and Tetiana Yeremeieva. 2016. "Vykorystannia avtentychnykh videomaterialiv dlia formuvannia komunikatyvnykh navychok u slukhachiv movnykh kursiv". Suchasni informatsiini tekhnolohii u sferi bezpeky ta oborony 1: 144-147.

5. Hurevych, Roman Maiia Kademiia, Mykhailo Koziar. "Informatsiino-komunikatsiini tekhnolohii v profesiinii osviti maibutnikh fakhivtsiv". http://ito.vspu.net/repozitariy/Kademiia/book/1_15monogr.pdf

6. Kozlakova, Halyna. 2002. Informatsiino-prohramne zabezpechennia dystantsiinoi osvity: zarubizhnyi $i$ vitchyznianyi dosvid.Kyiv: Prosvita.

7. Merriam-Webster Dictionary. https://www.merriam-webster.com/dictionary/information $\% 20$ technologies

8. Nova ukrainska shkola: integrovane navchannia: tematychnuy $i$ diialnisnyi pidkhody. https://nus.org.ua/articles/integrovane-navchannya-tematychnyj-i-diyalnisnyj-pidhody-chastyna-1

9. Nova ukrainska shkola: kontseptualni zasady reformuvannia serednioi shkoly. 2016. https://mon.gov.ua/storage/app/media/zagalna\%20serednya/nova-ukrainska-shkola-compressed.pdf

10. Palamarchuk, Valentyna and Olena Baranovska. 2018. "Pedahohichni tekhnolohii navchannia v umovakh novoi ukrainskoi shkoly : vector rozvytku". Ukrainskyi pedahohichnyi zhurnal. Kyiv: Instytut pedahohiky Natsionalnoi akademii pedahohichnykh nauk Ukrainy, 3: 60-65. DOI 10.32405/2411-1317-2018-3-60-66 
11. Pinchuk, Olga and Oleksandra Sokolyuk. 2018. "Cognitive activity of students under conditions of digital transformation of learning environment". Informatsiini tekhnolohii v osviti. Kyiv : Institute of Information Technologies and Learning Tools of NAES of Ukraine, 3(36): 71-81. DOI: 10.14308/ite000675

12. Redko, Volodymyr. 2011. "Interaktyvni tekhnolohii navchannia snozemnoi movy". Kyiv: Ridna shkola 8-9: 28-35.

13. Savchenko, Raisa. 2017. "Klipove myslennia ta shkola: sumischaiuchy nesumisne". https://osvita.ua/school/57359/

14. Sheludchenko, Olha and Svitlana Sheludchenko. 2019. Eksperymentalnyi kurs «Kriz epokhy ta kontynenty». Chastyna I «Podorozh kontynentamy»: metodychni rekomendatsii (dlia 5 klasu). Lutsk : Vezha-Druk.

15. Sheludchenko, Olha and Svitlana Sheludchenko. 2020. Eksperymentalnyi kurs «Kriz epokhy ta kontynenty». Chastyna II «Zemlia: podorozh u chasi»: metodychni rekomendatsii (dlia 6 klasu). Lutsk : Vezha-Druk.

16. Smeliakova, Lidiia. 1992. Khudozhestvennyi tekst v obuchenii inostrannym yazykam v yazykovom vuze (teoriia i praktika otbora). SPb.: Obrazovaniie.

17. "TechTerms". https://techterms.com/definition/ict

18. Videometod : terminolohichnyi slovnyk. https://pidru4niki.com/16790422/pedagogika/terminologichniy_ slovnik_osnovi_didaktiki

19. World Āhoy Animation Series. https://www.youtube.com/channel/UCwFhxWXKpF2SVZZOXXOOOgA

20. Zabolotnyi, Volodymyr. 2010. "Dydaktychni zasady zastosuvannia multimedia u formuvanni metodychnoi kompetentnosti maibutnikh uchyteliv fizyky”. PhD diss., Kyiv.

Павлюк Алла, Шелудченко Светлана, Шелудченко Ольга. Использование информационнокоммуникационных технологий при организации факультативных занятий английского языка по принципу интегративного подхода. В статье идёт речь об экспериментальных курсах и факультативних занятиях как о способе расширить коммуникативное пространство в средней школе. Обозначены предпосылки для использования информационно-коммуникационных технологий. Акцентировано внимание на актуальности вопроса применения информационно-коммуникационных технологий в образовании с учётом 10 компетентностей Новой украинской школы. Подчёркнута важность видеометода как оптимальной формы организации факультативных занятий английского языка по принципу интегративного подхода. Прослежена корреляция современных средств визуализации и сформированной лингвокультурной компетенции.

Сравнивается значение понятий Information Technology и Information and Communication Technology с последующим выявлением отличий в их смысловом наполнении. Привлечено внимание к информационнокоммуникационным технологиям как к средству интенсификации учебного процесса, который мотивирует соискателей образования, обеспечивая при этом формирование лингвокультурной компетенции.

Определено содержание модуля «Земля: путешествие во времени» экспериментального курса «По эпохам и континентам», который способствует успешному изучению языкового материала в игровой форме. Обозначены восемь тематических блоков, а именно: «Ледниковый период», «Великий шёлковый путь», «Дарвин и теория эволюции», «Географические открытия прошлого и первое кругосветное путешествие», «Пирамиды Египта», «7 чудес Древнего мира», «Как открыли мир растений», «Викинги», которые составляют модуль, посвящённый короткому экскурсу в историю планеты, а также великих географических и научных открытий.

Доказана комплиментарность «кейс»-метода, который в виде ситуативных упражнений способствует формированию личности, эрудированной, социально активной, с развитым мышлением и способностью активно творчески и самостоятельно подходить к решению сформулированных практических задач. Оценено позитивное влияние «кейс»-метода при обучении соискателей образования, представляющих поколения $Z$ и Альфа с клиповым мышлением.

Приведены примеры заданий и ситуативних упражнений некоторых тематических блоков модуля «По эпохам и континентам». Подчеркнуто значение важности сочетания видеометода с книжными фрагментами для реализации образовательных целей. Продемонстрирован комплекс упражнений на примере тематического блока «Викинги».

Ключевые слова: видеофрагмент, экспериментальный курс, интеграция, информационнокоммуникационные технологии, образовательное пространство.

Pavliuk Alla, Sheludchenko Svitlana, Sheludchenko Olha. Information and Communication Technologies and their Application for Extracurricular Activities and English Classes on the principle of Integrative Approach. The article deals with the peculiarities of experimental courses and extracurricular classes applied in order to expand the communicative space at secondary school. The prerequisites to implement information and communication technologies have been defined. The priority of information and communication technologies and their application in the educational sphere has been emphasized with reference to 10 competences of the New Ukrainian School. The importance of the video method has been accentuated as the best means to arrange English extracurricular activities on the principle of integrative approach. The correlation of modern illustrative resources and the activated linguistic and cultural competence has been traced.

The notions Information Technology and Information and Communication Technology have been contrasted and their logical differences have purposefully been revealed. The information and communication technologies have been asserted as a tool to intensify education and encourage the competitors while shaping linguistic and cultural competence. 
The content list of the educational module "The Earth: Time Travel" which is treated as a component of the educational course "Across Epochs and Continents" has been outlined. Eight topical units, namely "The Ice Age", "The Silk Route", "Darwin and the Theory of Evolution", "The First Journey Around the World", "The Pyramids of Egypt", "The Seven Wonders of the Ancient World", "World of Plants", and "The Vikings", have been singled out. These topical units have been considered to clarify the issues concerning the background of the planet and spotlight great geographical and scientific discoveries.

The positive effect of the "case"-method presented in the form of contextual drills has been argued. The "case"method has been considered as a strategy to shape an intelligent and community-minded personality. The "case"-method has also been suggested as a complimentary one when educating children who are the representatives of generations $Z$ and Alpha.

The exercises and contextual drills concerning some topical units under consideration have been exemplified. The value of video method along with the reading fragments has been validated. The whole set of drills correlating with the topical unit "The Vikings" has been analysed.

Key words: a video segment, an experimental course, integration, information and communication technologies, educational space.

DOI: https://doi.org/10.32782/2410-0927-2020-12-24

УДК: [811.111+811+112.2+811.161.2]'373.46(045)

Оксана Петренко

\section{СИНОНІМІЧНІ ВІДНОШЕННЯ НІМЕЦЬКОМОВНИХ ТЕРМІНІВ У ГАЛУЗІ РОБОТОТЕХНІКИ}

У статті досліджено явище синонімії термінів німецької мови галузі робототехніки на матеріалі 1670 мовних одиниць, відібраних шляхом суцільної вибірки з 16 фахових джерел (фахові тексти з робототехніки). Окреслено причини, які зумовлюють потребу в дослідженні синонімічних відношень німецькомовних термінів робототехніки, предмета, об'єкта, методів та завдань. Розглянуто два протилежні погляди на проблему термінологічної синонімії. Ідентифіковано поняття синонім, дублет, синонімія, синонімічні відношення. Проведено зіставний аналіз синонімічних рядів на семантичному та структурному рівнях. Якщо більшість визначень синонімії в загальнолітературній мові грунтуються на близькості значення лексичних одиниць, то термінологічні синоніми визначаються як мовні одиниці, абсолютно тотожні за значенням і взаємозамінні в будь-якому контексті, а поняття «термінологічна синонімія» найбільш адекватно виражає наявність декількох найменувань для одного означуваного. 3 погляду походження та структурно-словотвірних особливостей виокремлено вісім різновидів груп синонімів, до складу яких увійшли 159 синонімічних пар досліджуваної термінології: іншомовний термін - німецький термін (19\%), різнокореневі складені слова (17 \%), спільнокореневі складені слова (14 \%), терміни-однословибагатокомпонентні складені слова (13\%), німецькі різнокореневі синоніми (13\%), повне (німецьке або іншомовне) та скорочене найменування (12\%), терміни-композити - термінологічні сполучення (9 \%), німецькі однокореневі синоніми - (3\%). Найбільший синонімічний пласт у досліджуваній термінології складають дублетні терміносиноніми іншомовного та німецького походження. Це пов'язане із запозиченням іншомовних слів та штучним утворенням термінів на базі німецької мови 3 метою уникнення запозичень та створення власних термінів. Рекомендується у фаховій мові уникати синонімічних термінологічних найменувань та узаконювати лише одне найменування. Визначено перспективи подальших досліджень лексико-семантичної організації німецькомовної терміносистеми в галузі робототехніки.

Ключові слова: термін, терміносистема робототехніки, синонім, синонімія, синонімічні відношення.

Вступ. Останнім часом з інтенсивним розвитком суспільства, науки і нових технологій все більшого значення в лінгвістиці набувають дослідження, присвячені проблемам лексикосемантичних відношень терміносистем різних наук. У зв'язку з цим стає очевидною актуальність дослідження: вироблення єдиної впорядкованої термінології в галузі робототехніки, яка була б спрямована на усунення наявних протиріч, тобто на реалізацію принципу однозначності в розкритті поняття, що стосується певного терміна. На особливу увагу заслуговує питання термінологічної синонімії, пов'язане із проявами парадигматичних зв'язків у термінологічному просторі, постає проблема надмірності засобів формального вираження понять, на позначення якої вживаються такі терміни, як: термінологічна варіантність, термінологічна синонімія, дублетність або еквівалентність термінів. 